\title{
Nekrológ
}

\section{JEROME BRUNER (1915-2016)}

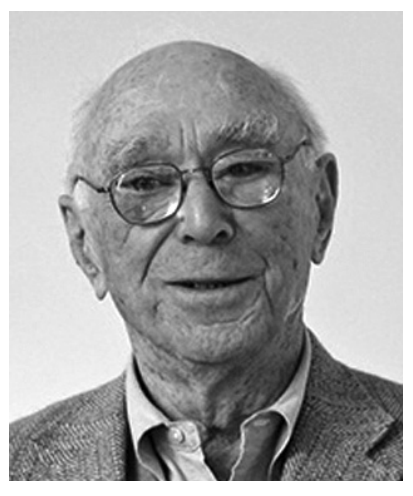

Jerome Bruner a kognitív pszichológiai és a modern oktatáskutatás vezéralakja, 2001-tôl az MTA tiszteleti tagja, 2016. június 6-án elhunyt. Bruner az utóbbi fél évszázad pszichológiájának egyik alapvetô formálója volt, s 100 éves életkorát is igen aktívan élte meg Munkássága négy szakaszra bontható, s mind a négy szakasz alapvetôen hozzájárult a modern pszichológia emberképének alakulásához. Elsố korszakában (1945-57) az észlelés új aktív elméletének kidolgozásával foglakozott, ezt követôn a kognitív pszichológia a belsố feldolgozást kiemelô elméletalkotója a Harvardon (1957-1970), majd a csecsemókor és a korai nyelvhasználat kutatója Oxfordban (1970-1980), végül 1990-tôl New Yorkban a narratív pszichológia elméletének részletes kidolgozójaként vált ismertté.

A fiatal Bruner a Harvard Egyetemen az emberi észlelés kontextus és értékfüggését hirdetô Új Szemlélet (New Look) egyik kísérleti megalapozója és szintetizátora volt. Ez a szemlélet lesz saját konstrukcionizmusának kiindulópontja, mint interjújában maga is elmondta (Pléh, 2001). Bruner (1983a), aki hályoggal, vakon született, s csak mútét után kezdett látni, saját tapasztalatai s az amerikai társadalmi élet attitûd s társadalmi helyzet befolyásolta észlelési helyzeteit vizsgálja (Bruner és Goodman, 1947), s így jut el ahhoz a felfogáshoz, mely szerint az észlelés mindig a helyzet s a személy függvénye (Bruner, 1957, 1973). Az aktív észlelést képviseló Bruner a magyar pszichológiában is nagy hatást gyakorolt, elsôsorban Marton Magda $(1975,1982)$ értelmezó munkáján keresztül. 
Bruner a konstrukcionista felfogást képviseli szervezó munkájában is, 1960-ban szervezte meg George Millerrel a Harvard Kognitív Kutatóközpontját, mely a Harvardon Skinner által képviselt viselkedô ember helyett a megismerô, a világot leképzó ember megértését helyezte a középpontba. A gondolkodási kategóriákat s a fogalomalkotás menetét vizsgálva úttörô módszerekkel kialakította az aktív kategória építô fogalomalkotás s a gondolkodási stratégiák hozzá kapcsolódó koncepcióját (Bruner, Goodnow és Austin, 1956). Bruner ugyanekkor bekapcsolódott a modern fejlôdéslélektani kutatásba is. Sokat tett Vigotszkij amerikai megismertetéséért, s a fejlődéslélektanban a kommunikációs mozzanatot állította elôtérbe Piaget „puszta” cselekvési felfogásával szemben. A modern kognitív fejlôdéslélektanban a reprezentációs váltások elméletének elsô kidolgozója. Felfogásában a gyermek elsô fejlődési korszakában cselekvési, azután képi-hasonlósági, majd harmadik szintként szimbolikus reprezentációkkal közelít a világhoz (Bruner, Olver és Greenfield, 1966). Az amerikai pragmatikus hagyományra építve a jelek világa ebben a felfogásban sokkal nagyobb szerepet fog játszani: maga a cselekvéses problematika is megkapja kommunikációs értelmezését. Brunernek ez a koncepciója igen nagy hatású volt az egész kognitív fejlôdési irodalomban. Magyarországon is tankönyvi anyaggá vált az elmúlt évtizedek során.

Bruner (1962) korán észrevette aktivista és a személy konstruktív szerepét kiemelő felfogásának átfogó társadalmi és pedagógiai sugallatait. John F. Kennedy és Lyndon B. Johnson amerikai elnökök tudományos tanácsadója volt, s nagy szerepet játszott a Nagy Társadalom kompenzációs nevelési programjainak (Head Start) kialakításában.

Ennek a kiterjesztésnek a keretében vált Bruner a modern pedagógiai konstrukcionista elméletek egyik kifejtőjévé. A gyermek aktív tanuló ebben a felfogásban, s mindenkinek megfelelố módon minden megtanítható. A tanterveket a gyermek szintjéhez igazítva spirálisan kell tervezni (Bruner, 1968). Az intézmények s a kultúra mintegy kereteket, Bruner (1972) saját kifejezésével ácsolatot adva támogathatják a tudás építését, de nem indoktrinálják a gyermeket.

A cselekvési és társas hangsúly jellemzi harmadik nagy kutatási területét az 1970-es években. Bruner az egyike a mai „kompetens csecsemő” elméletek elófutárainak, aki a kognitív teljesítmények társas kereteit, a közös figyelmi helyzeteket vizsgálja (Scaife és Bruner, 1975). A csecsemó korai nyelvfejlődését is társas keretekben s a használati mozzanatot kiemelve vizsgálja. Ô vezeti be elôször a korai megfigyelés szemmozgásos technikáit, s olyan felfogást képvisel, amelyben a gyermek korai közlései társas cselekvési keretben keletkeznek s társas célokat szolgálnak (Bruner, 1974, 1983b). Ez a keret máig vezetô megközelítés a korai gyermeknyelv s a csecsemókori megismerés kutatásában. Alison Gopnik, Alan Leslie, Andrew Meltzoff, Anat Ninio követik ezen az úton, sokszor túllépve a mesteren, s jóval biologisztikusabban értelmezve a társas mozzanatot, mint ahogy az Bruner eredeti „ácsolat” koncepciójában szerepelt. A magyar Kalmár Magda ebben a korszakban volt Bruner diákja, s ezt a Brunert ismertük meg a hetvenes években az MTA székházban tartott Chomskyval polemizáló elôadásából.

Az 1980-as évektôl a New York Universityn dolgozó Bruner vált a modern narratív pszichológiai megközelítés megalapozójává. Ebben a felfogásban a kategorikus és idôtlen tudományos leírásmód mellett kisgyermekkortól kezdve velünk él egy idôileg szervezett, antropomorf okozási sémákat alkalmazó elbeszélő keret. Ez a kettôsség adja a klasszikus természet és szellemtudomány viták gyökerét, de a társadalom meg- 
értésének és az oktatás újraszervezésének kulcsát is (Bruner, 2004, 2005). A történetmondás életünk s identitásunk legföbb szervezó elve, mely értelmet, összefüggést ad saját életünknek s a társas világnak. De ez irányítja számos jelentôs gyakorlati érdekteli életszféránkat, például a jogi diskurzus világát is (Amsterdam és Bruner, 2000).

Bruner narratív szemlélete a hazai pszichológiában László János (2005, 2012) munkái révén vált elismertté, s egyben a pszichológia és társadalomtudományok összekapcsolási keretévé is.

Bruner munkássága azt a klasszikus törekvést képviseli a jövô számára, mely a pszichológiát céljában s gyakorlataiban is a változó és nyitott ember megértésének átfogó tudományaként egyén és kultúra találkozási pontjaként értelmezi.

\section{IRODALOM}

Amsterdam, A. G., \& Bruner, J. S. (2000). Minding the Law. Cambridge, MA: Harvard U Press.

Bruner, J. (1957/1974). A perceptuális készenlétről. In Marton L. M. (szerk.), A tanulás szerepe az emberi észlelésben (pp. 125-170). Budapest: Gondolat.

Bruner, J. (1962). On Knowing Essays for the Left Hand. Cambridge, MA: Harvard U Press.

Bruner, J. (1968). Az oktatás folyamata. Budapest: Tankönyvkiadó.

Bruner, J. (1972). Új utak az oktatás elméletéhez. Budapest: Gondolat.

Bruner, J. (1973). Beyond the information given. New York: Norton.

Bruner, J. S. (1974). From communication to language. A psychological perspective. Cognition. 3. 225-287. Magyarul: In Pléh Cs. (szerk.), Szöveggyüjtemény a pszicholingvisztika tanulmányozásához (pp. 455-486). Budapest: Tankönyvkiadó.

Bruner, J. (1983a). In Search of Mind: Essays in Autobiography. New York: Harper.

Bruner, J. (1983b). Child's talk: Learning to Use Language. New York: Norton.

Bruner, J. (1985). Actual Minds and Possible Worlds. Cambridge, MA.: Harvard University Press.

Bruner, J. (2004). Az oktatás kultúrája. Budapest: Gondolat.

Bruner, J. (2005). Valóságos elmék, lehetséges világok. Budapest: Új Mandátum.

Bruner, J. S., Goodnow, J. J., \& Austin, G. A. (1956). A study of thinking. New York: Wiley.

Bruner, J., \& Goodman, C. C. (1947).Value and Need as Organizing Factors in Perception. Journal of Abnormal and Social Psychology, 42, 33-44.

Bruner, J. S., Olver, R. R., \& Greenfield, P. M. (1966). Studies in cognitive growth. New York: Wiley.

László J. (2005). A történetek tudománya. Budapest: Új Mandátum.

László J. (2012). Történelemtörténetek. Budapest: Akadémiai Kiadó.

Marton L. M. (1975). A tanulás szerepe az emberi észlelésben. In Marton L. M. (szerk.), A tanulás szerepe az emberi észlelésben (pp. 5-41). Budapest: Gondolat.

Marton L. M. (1982). Nem-tudatos folyamatok vizsgálata és értelmezése az általános lélektanban. Pszichológia, 2, 157-193.

Pléh Cs. (2001). Új arcok az Akadémián. (Hunyady György, Hernád István, Jerome Bruner, Daniel Dennett, Lénárd László, Buzsáki György). Magyar Pszichológiai Szemle 56, 427-442.

Scaife, M., \& Bruner, J. (1975). The Capacity for Joint Visual Attention in the Infant. Nature, 253, 265-266. 